\title{
RANCANGAN APLIKASI MONITORING PRODUKSI DAN PENGIRIMAN DENGAN METODE SHORTAGE DI PT. INDAH KIAT PULP \& PAPER SERANG MILL TBK
}

\author{
Kania $^{1}$, Ely Nuryani ${ }^{2}$, Azwarsyah ${ }^{3}$ \\ Universitas Banten Jaya \\ Jl. Syeh Nawawi Al-Bantani, Boru, Curug, Serang - Banten, Indonesia \\ Email: kania@unbaja.ac.id ${ }^{1}$, elynuryani@unbaja.ac.id ${ }^{2}$, azwarsyah@gmail.com $^{3}$
}

\begin{abstract}
Design of production and delivery monitoring applications at PT. Indah Kiat Pulp \& Paper Serang Mill Tbk aims to reduce problems in the production control process. The problems faced are as follows; the production process carried out by several parts results in slow processing of products, often duplicate data orders that can harm the company, the production of damaged products is not recorded, the number of reprimands from customers due to delay in delivery time due to ordering deficiencies the company must reset the production schedule. Based on these problems computer-based method (IT) shortage is needed. System design uses the waterfall method or SDLC (System Development Life Cycle). Software modeling uses UML (unified model language). The application has advantages such as the more structured and well-documented because the procedure is in accordance with the rules made by the Converting Division at PT. Indah Kiat Pulp \& Paper. This application is expected to be able to overcome all existing constraints, especially in managing production data. Based on the things mentioned above, the authors are interested in compiling articles about the design of Production and Delivery Monitoring Applications with the Shortage Method at PT. Indah Kiat Pulp \& Paper Serang Mill Tbk.
\end{abstract}

Keyword : Monitoring, Production, Delivery, Shortage Method

\section{PENDAHULUAN}

Komputerisasi tidak hanya mempengaruhi kita secara pribadi, tetapi juga mempengaruhi masyarakat, organisasi-organisasi, perusahaan-perusahaan, instansi pemerintah dan. teknologi komputer berkembang seiring dengan waktu yang terus bergulir dari masa ke masa pada saat ini, sehingga mengambil peranan yang sangat penting dalam perusahaan khususnya pada PT. Indah Kiat Pulp \& Paper Serang Mill Tbk.

PT. Indah Kiat Pulp \& Paper Serang Mill Tbk adalah salah satu perusahaan pembungkus kertas satu-satunya terbesar yang berlokasi di serang profinsi Banten, Indonesia. dengan 550 hectare fasilitas dan strategis yang di utamakan dalam distribusi, PT. Indah Kiat Pulp \& Paper Serang Mill Tbk berdiri pada tahun 1991, mempunyai beberapa gedung produksi kertas white grade dan brown grade 
salah satunya divisi converting / Pengubah memproduksi box kertas dengan bahan dasar brown grade yang mana berbagai macam pembungkus semua produk yang berbentuk box.

Divisi converting juga turut berperan aktif dalam peranan teknologi informasi, seiring dengan perkembangan teknologi yang begitu pesat dan terasa manfaatnya dalam membantu permasalahan dalam suatu proses kegiatan, dan kebutuhan dalam pengolahan data sangat dibutuhkan suatu aplikasi untuk membantu kualitas perusahaan dalam menangani masalah-masalah yang ada.

Saat ini monitoring produksi dan pengiriman pada divisi converting PT. Indah Kiat Pulp \& Paper Serang Mill Tbk. dalam proses kontrol produksi sendiri masih banyak campur tangan beberapa karyawan yang mengakibatkan lambatnya proses pengolahan data, sering terjadinya double pembuatan order dan merugikan perusahaan, tidak terdatanya hasil produksi yang rusak, banyaknya teguran dari pelanggan karena ketepatan tanggal pengiriman karena untuk order kekurangan / shortage harus diatur ulangnya jadwal produksi.

Berdasarkan permasalah di atas, maka perlu ditemukan pemecahan masalah dalam mengatasi masalah tersebut yaitu perlu adanya aplikasi yang berbasis data untuk mengkontrol proses pengolahan data kekurangan produksi dan ketepatan pengiriman sehingga proses produksi dan pengiriman, dapat terlaksana dengan cepat dan akurat yang di desain dengan menggunakan pemrograman PHP, dan SQL Server.

\section{METODE PENELITIAN}

Metode Pengumpulan data adalah sebagai berikut :

1) Penelitian Lapangan (Field Research), metode penelitian ini dilakukan langsung pada objek penelitian, data secara keterangan yang dikumpulkan dilakukan dengan cara:

2) Pengamatan (Observation), penulis melakukan pengamatan untuk mendapat kan data secara umum dengan melihat langsung, mengamati dan mencatat sistem yang sedang berjalan saat ini serta melihat format-format yang dilakukan selama ini. 
3) Wawancara (Interview), penulis melakukan wawancara untuk melengkapi bahan yang sudah ada selama observasi. Penulis melakukan tanya jawab kepada staf atau karyawan PT. indah kiat pulp \& paper tbk yang berkaitan dengan sistem yang sedang berjalan.

\section{Metodologi Perancangan Aplikasi}

Metodologi perancangan aplikasi yang penulis gunakan adalah metode SDLC (Sistem Development Life Cycle) atau sering disebut sebagai pendekatan air terjun (waterfall). Rosa A.S. dan M. Shalahuddin, (2013:28) mengungkapkan bahwa model SDLC air terjun (water fall) sering juga disebut model sekuensial linier (sequential linear) atau alur hidup klasik. Model air terjun menyediakan pendekatan alur hidup perangkat lunak secara sekuensial atau terurut dimulai dari analisis, desain, pengodean, pengujian dan tahap pendukung (support).

\section{Pemodelan Aplikasi UML}

Menurut Adi Nugroho 2010, UML (Unified Modeling Language) adalah Bahasa pemodelan untuk sistem atau perangkat lunak yang berparadigma berorientasi objek. Pemodelan (modeling) sesungguhnya digunakan untuk penyederhanaan permasalahan-permasalahan yang kompleks sedemikian rupa sehingga lebih mudah dipelajari dan dipahami.

Beberapa literature menyebutkan bahwa UML menyediakan sembilan jenis diagram, yang lain menyebutkan delapan karena ada beberapa diagram yang digabung, misanya diagram komunikasi, diagram urutan dan diagram pewaktuan digabung menjadi diagram interaksi. Namun demikian model-model itu dapat dikelompokkan berdasarkan sifatnya yaitu statis atau dinamis.

\section{PEMBAHASAN}

\section{Sejarah Singkat Organisasi PT. Indah Kiat Pulp \& Paper Tbk}

PT. Indah Kiat Pulp \& Paper Tbk adalah salah satu perusahaan pembungkus kertas satu-satunya terbesar yang berlokasi di serang profinsi Banten, Indonesia. dengan 550 hectare fasilitas dan strategis yang di utamakan dalam distribusi, pelabuhan. PT. Indah Kiat Pulp \& Paper Tbk berdiri pada tahun 1991, mempunyai solusi untuk kebutuhan semua kertas dan kebutuhan 
pembungkus makanan.Kami menjalankan dua group mesin kertas, empat mesin produksi kertas coklat/industri antara lain dua mesin kertas putih, masih dalam penambahan untuk memproduksi kertas PT. Indah kiat juga mempunyai gedung produksi pengubah produksi pengubah pelipat kertas yang mana berbagai macam pembungkus semua produk dibagikan pada semua negara termasuk Asia, utara dan South America, Australia, Africa, dan negara Europe. The Mill agregat kapasitas produksi tahunan sekitar 1.700 .000 metrik ton kertas karton dan 480.000 metrik ton untuk dikonversi produk dan kotak lipat.

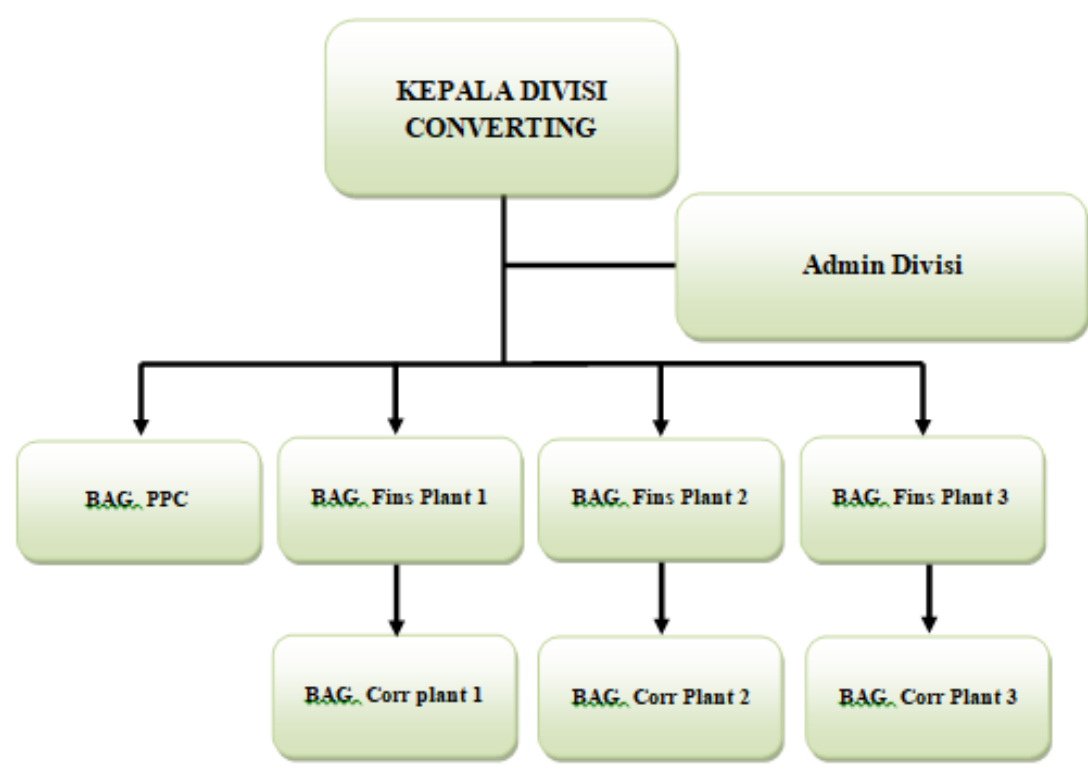

Struktur Organisasi Divisi Converting

Menurut Wignjosoebroto (2013), biaya kelangkaan atau shortage costs yaitu biaya yang harus dikeluarkan sebagai konsekuensi kekurangan atau kelangkaan persediaan. Mulyono (2012) menyatakan, shortage atau stockout costs tercipta jika permintaan tak dapat dipenuhi karena kekosongan persediaan termasuk dalam kelompok ini adalah ketidakpuasan konsumen dan potensi keuntungan yang tak terealisasi. Sangat sulit memperkirakan shortage cost, sebagai gantinya dilakukan perkiraan subjektif. Shortage Cost berhubungan terbalik dengan holding cost. Jika persediaan bertambah, holding costs bertambah sementaara shortage costs berkurang. Istilah Shortage dikenal dengan pengertian suatu keadaan di mana terjadi kelebihan permintaan. Harga keseimbangan ditentukan oleh kekuatan permintaan dan penawaran. Penjual dan pembeli 
biasanya akan selalu mengambil tindakan yang bertujuan untuk mencapai keseimbangan antara pemintaan dan penawaran. Situasi di mana jumlah penawaran lebih besar dari permintaan disebut dengan surplus. Sebaliknya, situasi di mana jumlah permintaan lebih besar dari pernawaran disebut dengan kekurangan (shortage).

Berdasarkan identifikasi dan pengamatan yang dilakukan penulis maka dapat digambarkan sebagai berikut:

\section{A. Use Case Sistem Berjalan}

Use Case diagram menggambarkan interaksi antara user dan sistem eksternal, dengan kata lain secara grafikal mendeskripsikan siapa yang akan menggunakan sistem dan dengan cara seperti apa sesuai dengan yang di harapkan user untuk berinterkasi dengan sistem.

Use Case sistem yang tengah berjalan adalah sebagai berikut:



Gambar 1. Use Case Aplikasi Monitoring Produksi yang berjalan 


\section{B. Rancangan Usulan:}

Berdasarkan analisis kebutuhan yang telah dilakukan pada tahap awal penelitian maka penulis mengajukan usulan rancangan aplikasi sebagai berikut;

\section{Use Case Diagram Shortage Method}

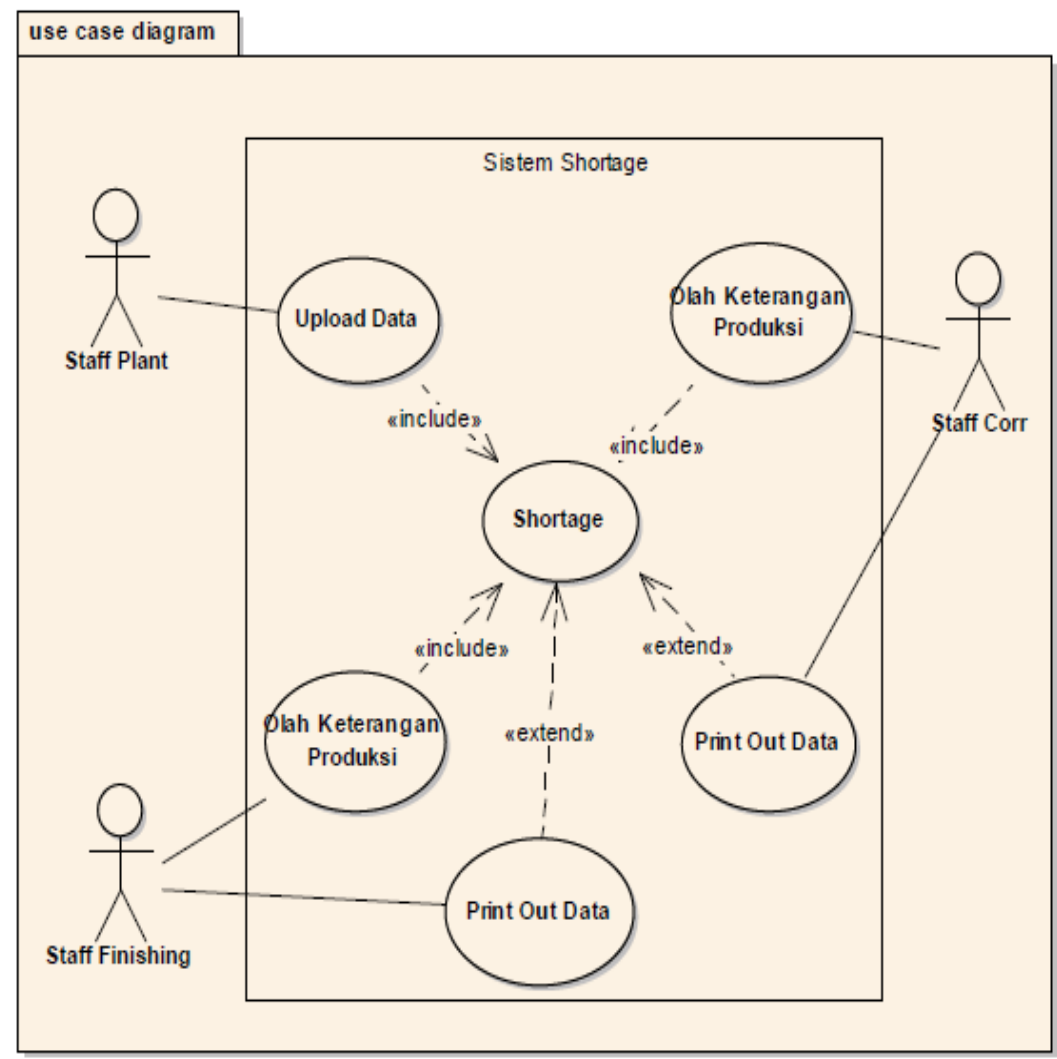

Gambar 2. Use Case Diagram Shorttage Method 


\section{Rancangan Prototype Aplikasi}

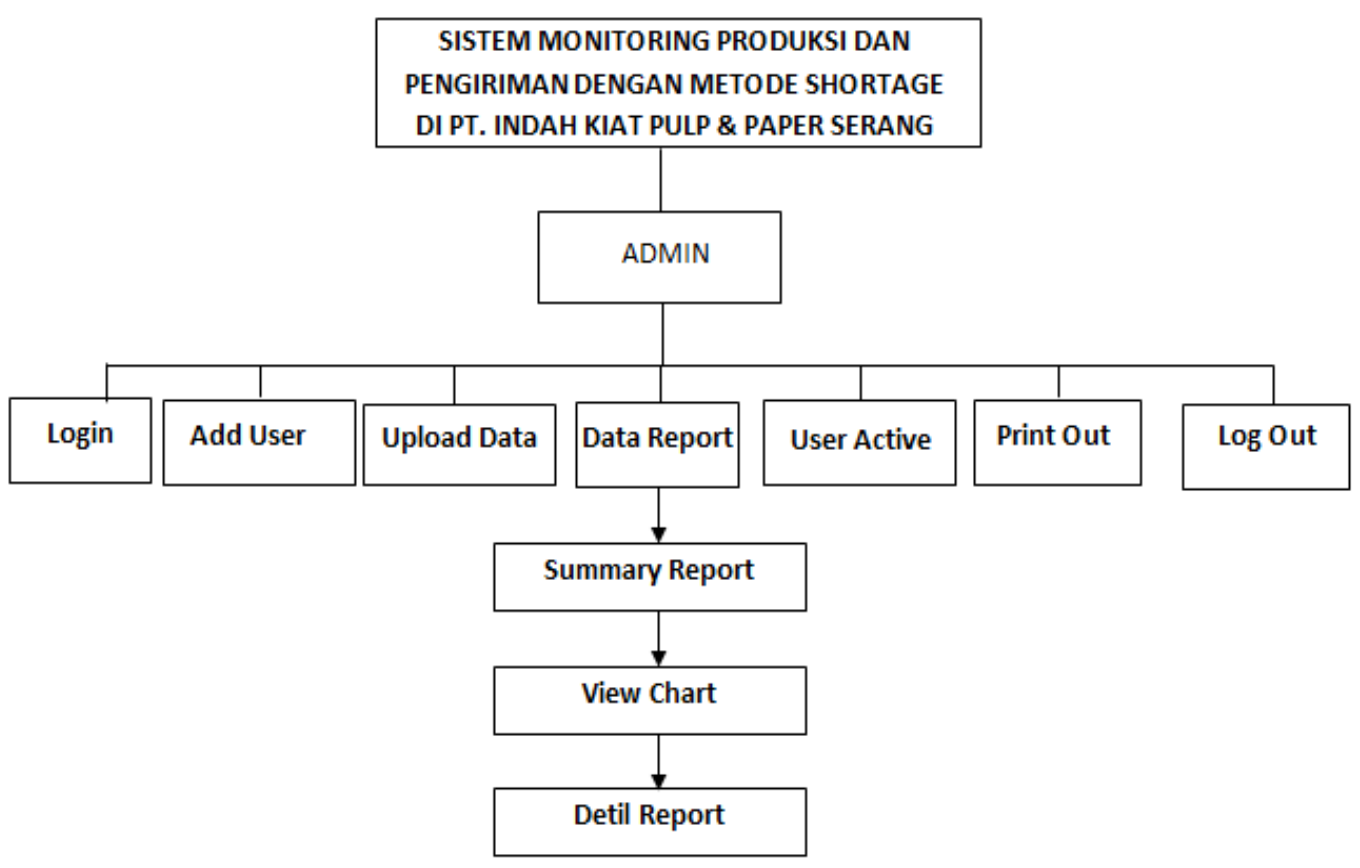

Gambar 3. Struktur Tampilan Aplikasi

\section{SIMPULAN}

Berdasarkan hasil penelitian yang telah dilaksanakancdapat disimpulkan bahwa, dengan adanya aplikasi ini maka ini proses pengolahan data bisa cepat dan akurat, menghindari redundancy pembuatan order produksi sehingga tidak menyebabkan kerugian perusahaan, barang yang rusak dan sisa-sisa produksi dapat terdata dengan baik, pengiriman produk bisa cepat dan akurat.

Dalam penerapan aplikasi ini maka saran yang sekiranya bermanfaat untuk PT. Indah Kiat Pulp \& Paper Serang Mill Tbk yaitu sebagai berikut; bagi user dan operator diharapkan mengikuti pelatihan agar aplikasi yang baru dapat berfungsi sebagai mana mestinya, aplikasi yang baru diterapkan harus dilakukan uji coba terlebih dahulu, terutama kepada user atau operator. User atau operator harus diberikan pelatihan tentang petunjuk pengoperasian aplikasi yang baik sehingga dalam menjalankan terhindar dari kesalahan-kesalahan.

\section{DAFTAR RUJUKAN}


Assauri, Sofyan, 2009, Manajemen Produksi dan Operasi Edisi Revisi. Jakarta : FE-UI

Edhy, Sutanta, 2011, Analisa Sistem Basis Data. Yogyakarta : Graha Ilmu

Fowler, Martin, 2015, Unified Modeling Language Edisi 3. Yogyakarta: Andi Offset

Holy, Icun Yunarto, 2005, Business Concept Implumentation Series. : In Sales And Didrtibution Management. PT. Elex Media Komputindo. Jakarta.

Jogiyanto, 2014, Pengenalan Komputer, Dasar Ilmu Komputer, Pemrograman, Sistem, Informasi dan Intelegensi Buatan. Yogyakarta : Andi Offset

Kadir, Abdul, 2005, Dasar Pemrograman Web dengan ASP. Yogyakarta: Andi Offset

Nugroho, Adi, 2010, Rekayasa Perangkat Lunak Berbasis Objek dengan Metode USDP. Yogyakarta : Andi

Peranginangin, Kasiman,2006, Aplikasi Web Dengan PHP dan MySQL. Edisi I. Yogyakarta : Andi

Rosa A.S dan Shalahuddin, M, 2011, Modul Pembelajaran: Rekayasa Perangkat Lunak, Modula. Bandung : Informatika.

Sucipto, S.Kom, 2011, Konsep dan Teknik pengembangan Sistem Berbasis Teknologi Informasi. Provinsi Banten: Dinas Pendidikan

Sunarfrihantono, Bimo, 2012, PHP Dan MySQL Untuk Web. Yogyakarta: Andi

Sritomo, Wignjosoebroto, 2012, Pengantar Teknik \& Manajemen Industri. Surabaya : Guna Widya

Legowo, Nilo \& I Made Kresna Yoga , 2012, Jurnal Perancangan Aplikasi Monitoring Produksi Pada Perusahaan Yang Memproduksi Acrylic. ComTech Vol.3 No. 1 Juni 2012: 676-685

Mardiani, Gentisya Tri, 2013, Kajian Sistem Monitoring Dokumen Akreditasi Teknik Informatika Unikom. Jurnal Ilmiah Komputer dan Informatika Vol. 2, No. 1, Maret 2013, ISSN : 2089-9033. Hal. 35-40 